\title{
The Influence of Physical Activities on Biological Age Parameters of the First-Year Female Students from An Giang University-Viet Nam
}

\author{
Dao Chanh Thuc* \\ Department of Physical Education, An Giang University, Vietnam
}

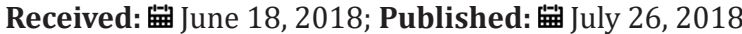

*Corresponding author: Dao Chanh Thuc, Department of Physical Education, An Giang University, Vietnam.

\begin{abstract}
To determine the effect of weekly physical activity on biological age (BA) parameters, we conducted a study among 265 first-year female students who were divided into the experimental ( $E G, n=135)$ and control (CG, $n=130)$ groups. It was established that if at the end of the experiment the BA parameters of the CG girls did not differ significantly from the average data of the university ( $p>0.05)$, then there was a statistically significant decrease in the BA parameters of the EG girls. This was confirmed by statistical probability $(\mathrm{p}<0.01)$, which suggests the dependence of biological age parameters on the extent of weekly physical activity.
\end{abstract}

Keywords: Biological age; Student; Physical activity; An Giang University

\section{Introduction}

Apanasenko et al. [1], developed a simple and accessible method of human health status assessment for qualification of nursing staff and health professionals in the field of physical culture and sports. Scientific studies have found that 25 years ago, about $8 \%$ of the population had the "safe» health status, and now-less than $1 \%$. Thus, according to HL Apanasenko (2015), it is reasonable to believe that this situation is the medical and biological basis of depopulation in Viet Nam.

Apanasenko et al. [1], Thuc DC [2] have shown an increase in the rates of Vietnamese student youth ageing, in particular: biological degradation of species (decline of population health «quantity» (viability)), epidemics of chronic non-infectious diseases, and decrease in reproductive function. For comparison, if the average difference between the passport and biological age of the Dutch youth is 15 years, then in Vietnamese student youth - 30 years (at the beginning of 2016-2017 academic year, the biological age of 17 year-old female students was 40 years, and the biological age of male students was 55 years, although during 2004-2005 academic year, the biological age of female students was 31 years old, and the biological age of male students was 39 years old).

In order to assert to what extent the degree of ageing is consistent with the chronologic age, it is necessary to compare the individual biological age with a proper biological age (PBA), which characterizes the population standard for age-related depreciation. Having calculated the index of biological age (BA/PBA), it is possible to find out what fold the biological age of the subject is greater or less than the average biological age of his/her peers [3]
Having calculated the index of biological age, it is possible to find out how many years the subject is more or less aged then his/ her peers. If the subject ageing rate is less than the ageing rate (on average) of persons with equal chronological age, then BA/PBA is < 1 , and $\mathrm{BA}-\mathrm{PBA}$ is $<0$. If the subject ageing rate is greater than the ageing rate of persons with equal chronological age, then BA/PBA is $>1$, and $B A-P B A$ is $>0$. If the ageing rates of this subject and his/ her peers are equal, then $\mathrm{BA} / \mathrm{PBA}=1$, and $\mathrm{BA}-\mathrm{PBA}=0$ [4].

Gerontologists had to introduce the concept of «biological age» following they were convinced of the difference in ageing of the human body systems. Each organ is appeared to live on its own individual schedule. The heart, lungs, nervous system wear out the fastest, and the digestive organs a while later. Therefore, peers often look differently. Above all, people with hypertension, diabetes mellitus and overweight patients are biologically older than their peers. According to, in theory, the biological age should coincide with the passport one (2-3 years more or less). However, if the index of biological age exceeds the passport data for 9-10 years, it is a disaster.

\section{Materials and Methods}

To determine the effect of weekly physical activity on the BA parameters, we conducted a study of 265 first-year female students who were divided into experimental (EG, $n=135$ ) and control (CG, $\mathrm{n}=130$ ) groups. The study of the pedagogical experiment lasted throughout the academic year. During the experiment, the effect of physical activity on the biological age parameters of the EG 
girls was determined. In the study, the statistical probability of difference between the biological age of girls in the experimental and control groups in relation to the university average data was determined using the Student's test, as well as changes of the results over time in each study group was evaluated. The aim of the article is to study the influence of physical activities on changes in the biological age parameters of the first-year female students from An Giang University.

\section{Tasks}

a) To study the dependence between the biological age of the first-year female students and a weekly physical activity.

b) To develop and test the model of weekly health-improving physical activity and sports activity of the first-year female students.

\section{Research Methods}

Theoretical analysis and generalization of scientific and methodical literature, pedagogical observation, testing, pedagogical experiment, methods of mathematical statistics.

\section{Results}

Throughout the entire period of studying at a university, a whole range of tasks must be addressed, among which the following is a priority: to reduce the number of illnesses, to improve health and to increase the level of students' physical fitness and secondary to that, to improve the mental performance of students. Consequently, it is necessary to create and maintain an environment and a microclimate in a higher educational establishment that will contribute to the formation of goals, values, principles of healthy lifestyle and control over the factors that determine or affect the student's health [3].

The student's purposefulness, life activity or, conversely, passivity depends on his/her values. The developed system of values in students incites them to take health-improving actions and to adhere to the requirements of a healthy lifestyle. The student's system of values is not unchanged. The person lives and is formed in the conditions of the social environment, living conditions, the system of education and upbringing; the system of values changes from a course to a course; new values appear; the old ones are reappraised and re-evaluated. The health state, living conditions and material well-being, as well as level of physical fitness, etc., make allowances to the hierarchy of vital values of the student's personality.

The most important urgent questions that scientists and practitioners have been looking for many years are as follows:

a) What are the social values, biological essence, norm, the real level, deterministic factor structure of students' health?

b) What should be done to create, strengthen, preserve and improve the students' health under the market-based relations?

c) How and by what factors we should influence the youth in order to educate their motivation to maintain health and improve mental and physical conditions?
The most important thing for evaluation of the body viability is given not by morbidity indicators, but by the general biological, non-nosological characteristics of this state, which is based not on the disease classification, but on the understanding of the disease itself. Such evaluation is presented by the human biological age [4].

Biological age is a generalized concept that reflects the individually achieved level of morphological and functional maturity of individual tissues, organs, systems, and the entire body. The biological age depends on the genetic features of growth and development, as well as on the environment, in which the individual lives, on the socio-economic, domestic, financial and other factors that determine the way of life. In contrast to the nosological diagnostics, which is qualitative in its nature and does not reflect the quantitative characteristics of the body state, the biological age allows us to assess the functional state of human systems and organs. Although known methods of biological age determining do not allow to measure the degree of molecular and genetic «ageing» caused by the deterioration of functional activity of the human body, and differences in conditions and lifestyles of different segments of population «erode» the correspondence between markers of ageing and viability, even under these restrictions, the biological age yet remains one of the most probable indicators of human vital activity. In the experimental program that we developed, students were provided with theoretical knowledge, and motivation for health improvement was formed. This program contributed to an increase in the level of physical fitness, to an increase in weekly motion state, performing various forms of active rest during the academic day, which in general is the basis of health-saving technologies (Table 1).

Table 1: Model of the weekly physical and sports activities of students in special medical groups.

\begin{tabular}{|c|c|c|c|}
\hline No & Organizational form & $\begin{array}{l}\text { Frequency and } \\
\text { extent }\end{array}$ & $\begin{array}{c}\text { Weekly extent } \\
\text { hours }\end{array}$ \\
\hline 1 & Morning exercises & $\begin{array}{l}\text { 30-35minutes } \mathrm{x} \\
\text { 6days }\end{array}$ & $\approx 3$ hours \\
\hline 2 & $\begin{array}{l}\text { Way to the university (as the } \\
\text { first walk) }\end{array}$ & $\begin{array}{l}\text { 30-35minutes } \mathrm{x} \\
\text { 5days }\end{array}$ & $\approx 2.5$ hours \\
\hline 3 & Classes on physical education & $\begin{array}{l}\text { 2hours per } \\
\text { week }\end{array}$ & 2hours \\
\hline 4 & $\begin{array}{l}\text { Active rest during the } \\
\text { academic day (a minute for } \\
\text { physical activity, physical } \\
\text { activity micropause) }\end{array}$ & $\begin{array}{l}\text { 15-20minutes } \mathrm{x} \\
\text { 5days }\end{array}$ & $\approx 1.5$ hour \\
\hline 5 & $\begin{array}{c}\text { Active rest while doing home } \\
\text { theoretical tasks (physical } \\
\text { activity pause, walk) }\end{array}$ & $\begin{array}{l}\text { 30-35minutes } \mathrm{x} \\
\text { 6days }\end{array}$ & $\approx 3$ hours \\
\hline 6 & $\begin{array}{l}\text { Independent physical } \\
\text { exercises or trainings in } \\
\text { sports sections }\end{array}$ & $\begin{array}{l}\text { 3times-1.5- } \\
\text { 2hours per } \\
\text { week }\end{array}$ & 4.5-6hours \\
\hline 7 & $\begin{array}{l}\text { Participation in physical and } \\
\text { sports events of the course, } \\
\text { faculty and university }\end{array}$ & $\begin{array}{l}\text { 2-3 times } \mathrm{x} \\
\text { 1 hour }\end{array}$ & 2-3hours \\
\hline
\end{tabular}

As Table 2 shows, there is no positive effect of physical education classes in CG girls (only 2 hours per week). BA parameters are almost the same as average values for the university (average values for 
the university $38.9 \pm 0.71$ vs. $39.03 \pm 0.68$ years in CG girls, $p>0.05$ ) In some cases, such a system of physical education negatively affects the health of student youth. Having physical activity once a week can lead to a negative feeling for the next few days (muscle aches, bad sleep, loss of appetite, sometimes headache, reluctance to attend physical education classes due to these symptoms, etc.).

Table 2: Dependence between biological age parameters of the first-year female students and weekly physical activity extent during the academic year $(n=265)$.

\begin{tabular}{|c|c|c|c|c|c|}
\hline & \multirow{2}{*}{$\begin{array}{c}\text { Statistical } \\
\text { parameters }\end{array}$} & $\begin{array}{c}\text { Average values } \\
\text { in the higher } \\
\text { educational } \\
\text { establishment }\end{array}$ & \multirow{2}{*}{$\begin{array}{c}\text { Control } \\
\text { group }\end{array}$} & \multicolumn{3}{|c|}{$\begin{array}{c}\text { Experimental group } \\
\text { (physical activity extent } \\
\text { on a weekly basis) }\end{array}$} \\
\cline { 5 - 7 } & & 2hours & 4hours & $\begin{array}{c}\mathbf{6} \\
\text { hours } \\
\text { and } \\
\text { more }\end{array}$ \\
\hline $\mathrm{M}$ & 38.9 & 39.03 & 39.79 & 40.04 & 35.01 \\
\hline$\pm \sigma$ & 0.71 & 0.68 & 0.98 & 0.91 & 0.92 \\
\hline $\mathrm{t}$ & & 0.34 & 1.12 & 1.18 & 5.49 \\
\hline $\mathrm{P}$ & & $>0.05$ & $>0.05$ & $>0.05$ & $<0.01$ \\
\hline
\end{tabular}

Girls of the $1^{\text {st }} \mathrm{EG}$, who had one physical education class for a week and two hours of independent training, showed a certain trend to increase in the BA parameters (from $38.9 \pm 0.71$ to $39.79 \pm$ 0.98 years; $p>0.05$ ) at the end of the experiment. A similar situation was observed in girls of the $2^{\text {nd }}$ EG (one physical education class and 4hours of independent trainings per week), in which the BA parameters at the end of the experiment remains at practically the same level (from $38.9 \pm 0.71$ to $40.04 \pm 0.91$ years; $p>0.05$ ).

The best result was obtained in girls of the $3^{\text {rd }}$ EG. Conduction of one class on physical education and another six and more independent hours of training per week, contributed to a significant reduction in BA parameters at the end of the experiment. Thus, the BA parameters of girls in the $3^{\text {rd }}$ EG are significantly lower than the average values at the university: $35.01 \pm 0.92$ vs. $38.9 \pm 0.71$. This is confirmed by statistical probability $(\mathrm{p}<0.01)$. The determined system of health-training classes has proven a high degree of efficiency and may be is a kind of standard in establishment of weekly motion status for students of a higher educational establishment. Biological age data indicate the high efficiency of the experimental method. The well-being of girls in the $3^{\text {rd }} \mathrm{EG}$ improved, oxygen capacity of the lungs increased, redox processes in the body increased, function of the gastrointestinal tract and excretory organs was normalized, coordination between the muscle activity and vegetative and trophic functions improved, etc. The results of our study coincide with the data of other Vietnamese scientists [5].

\section{Discussion}

The greatest effect is proved to occur while having six hours or more of independent training and two hours of physical education classes weekly. This is the minimum that girls should do in order to maintain good physical condition, as well as to influence on the biological age reduction. The main reasons for insufficient effect of physical activity on the biological age parameters of the first-year female students of An Giang University are:
The first and the main reason is insufficient number of hours of physical education classes. In general, educational establishments, girls receive 20 to $30 \%$ of the required motor activity, and in higher educational establishments, teachers begin to work with girls, in fact from the base level. Therefore, the number of hours for restoration, development and improvement of physical conditions, for motivation to self-improvement, for giving them the basics of physical education, must be significantly increased, then provided by the university's educational part [6-8].

The second reason is the low efficiency of physical education classes. The third reason is the non-adherence of the teacher's methodological recommendations regarding the organization and conduction of independent classes while planning of training activities. The fourth reason is the non-willingness of students to consult a teacher of the Physical Education Department when there are various questions related to the system of independent training activities. The fifth reason is not compliance with the schedule of independent training activities. The sixth reason is unformed motivation for their physical self-improvement.

\section{Conclusion}

The recommended model of the weekly motor activity of the first-year female students contributes to the provision of normal viability, health improvement, forming the motivation for physical self-improvement, success in learning and skills mastering of the future profession, as well as increasing in the weekly motor activity of the first-year female students to 17-20hours. The verification of experimental program effectiveness showed its more pronounced positive influence compared to the current program of physical education in higher educational establishments in Viet Nam. The relationship between biological age and a weekly extent of physical activity has been revealed.

\section{References}

1. Apanasenko H, Havryliuk V (2014) Biological degradation of HOMO SAPIENS: The ways of counteraction. Basics Concepts Methods Palmarium Academic Publishing. Heinrich-Bocking-Str, p. 96.

2. Thuc Dao Chanh (2017) Physiology of Sport. An Giang University, Viet Nam, pp. 180.

3. Stanislav P, Volodymyr T, Dmytro O, Yuriy P, Kostiantyn P, et al. (2018) The influence of physical activities on biological age parameters of the first-year female students from the special medical department. Journal of Physical Education and Sport 18(2): 561-564.

4. Bulych EH, Muravov IV (2003) Human health: The biological basis of viability and motor activity in its stimulation. Olympic literature, pp. 424 .

5. Chieu ND (2014) The health of healthy people. Introduction in sinology, Zdorovie, pp. 255.

6. Aghyppo A, Tkachov S, Orlenko O (2016) Role of physical education on the formation of a healthy lifestyle outside of school hours. Journal of Physical Education and Sport 16(2): 335-339.

7. Lam Quang Thanh, Nguyen Thanh Lam (2011) sports measurement. Ho Chi Minh University of Sport, Ho Chi Minh City, Viet Nam.

8. Prysiazhniuk SI (2004) Relationship between biological age and physical fitness of students of the National Agrarian University. Theory and Practice of Physical Education, p. 21-25. 
ISSN: 2574-1241

DOI: 10.26717/BJSTR.2018.07.001482

Dao Chanh Thuc. Biomed J Sci \& Tech Res

(C) (i) This work is licensed under Creative

Submission Link: https://biomedres.us/submit-manuscript.php

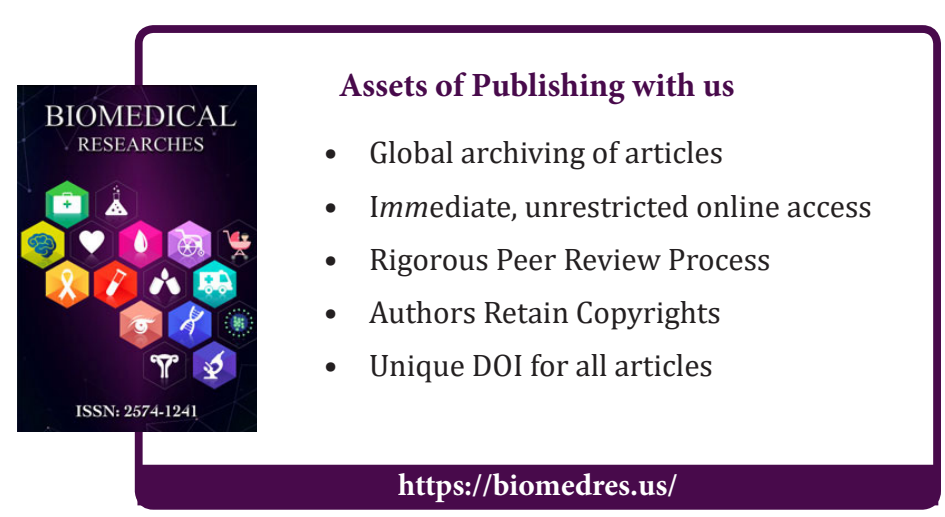

